\title{
MICROSURGICAL TREATMENT OF LUMBAR DISC HERNIATION: A RETROSPECTIVE REVIEW OF 282 CASES
}

\author{
${ }^{1}$ Medipol Health Group, Bahçelievler Private Nisa Hospital, Clinic of Neurosurgery, Istanbul, Turkey \\ ${ }^{2}$ Acıbadem Mehmet Ali Aydınlar University Vocational High School of Health, Department of First and Emergency Aid, İstanbul, Turkey \\ ${ }^{3}$ Acıbadem Mehmet Ali Aydınlar University Faculty of Medicine, Department of Neurosurgery, Istanbul, Turkey
}

\begin{abstract}
Objective: Lumbar disc herniation is an important disease that causes symptoms of back pain, leg pain, and imbalances in muscle strength in patients, causing socio-economic problems due to loss of workforce in the society. In this study, which was conducted from April 2015 to April 2017, we retrospectively evaluated the patients with lumbar disc herniation, who underwent microsurgery.

Materials and Methods: Microsurgery with maximum resection principle was performed on 282 patients. Of these patients, 125 were men and 157 were women. The mean age of the patients was 44 (19-80) years. Operations were planned by using lumbar X-ray and lumbar magnetic resonance imaging techniques. Computed tomography of the lumbar spine and electromyography were used to support the diagnoses when necessary. A retrospective evaluation of the patients was performed considering their gender, age, physical examination and radiological findings, disc distances, preoperative and postoperative findings, complications, recurrences, and patient satisfaction.

Results: Of the included patients, 125 were men (44.33\%) and 157 were women (55.67\%). The mean age was 44 (19-80) years. Among the study patients, pathological findings were found at the intervertebral disc between the L1 and L2 levels in three (1.06\%) patients, the L2 and L3 levels in eight (2.84\%) patients, the L3 and L4 levels in 32 (11.35\%) patients, the L4 and L5 levels in 103 (36.52\%) patients, and the L5 and S1 levels in 61 (21.63\%) patients. Pathological findings were present in two levels in 61 (21.63\%) patients, in three levels in 13 (4.61\%) patients, and in four levels in one $(0.35 \%)$ patient. The dural injury was identified in nine (3.19\%) patients, subcutaneous cerebrospinal fluid collection was present in one $(0.35 \%)$ patient, and a mislabeled laminotomy was found in one $(0.35 \%)$ patient. Spondylodiscitis developed in one $(0.35 \%)$ patient, superficial skin infections developed in two $(0.71 \%)$ patients, and postoperative spondylolisthesis occurred in one $(0.35 \%)$ patient to whom stabilization was applied. Recurrences developed in eight (2.84\%) patients and these patients underwent repeat surgery. According to the Prolo follow-up scale, the results of the surgery were excellent in 137 (48.58\%) patients, good in 124 (43.97\%) patients, moderate in 20 (7.09\%) patients, and poor in one (0.35\%) patient.

Conclusion: Our study results demonstrate that the microsurgical technique and maximal disc resection in selected cases of surgery are effective and reliable methods in the surgical treatment of lumbar disc herniation.

Keywords: Lumbar disc herniation, microdiscectomy, maximal resection
\end{abstract}

\section{INTRODUCTION}

The intervertebral disc was anatomically defined by Valsalius in 1555 for the first time. The link between low back pain and sciatica was revealed by Laseque in the 1800s. In 1925, Walter Dandy reported that the free disc material was the cause of the compression in two patients who he had operated. Intervertebral disc herniation treatment was introduced after the disease was first defined in the early $1930 s^{(9,20)}$. The intervertebral disc consists of three parts: the annulus fibrosus, the nucleus pulposus, and the cartilaginous plaque. In children, the nucleus pulposus is liquid; however, it is subject to dehydration and shrinkage over the years. Throughout this aging process, the content of the nucleus pulposus changes, too. Trauma, occurring either in the form of a single accident or being exerted constantly in the form of minor stress (for example, due to professional obligations), either leads directly to herniation or accelerates the development of further herniation ${ }^{(17,19,24)}$.

As it is known, lumbar disc herniation (LDH) is currently one of the major burdens in the society and economic settings due to a variety of symptoms including low back pain, leg pain, impaired muscle strength, and hypoesthesia. Although most patients are in the range from 30 to 50 years of age, LDH is diagnosed in children and adolescents, too ${ }^{(20,24)}$. Approximately $90 \%$ of all disc herniations in the spine are observed in the lumbar region. Only $5 \%$ of the painful cases are diagnosed with disc herniation. Up to $95 \%$ of LDH occur in the intervertebral disc areas between the $L 4$ and $L 5$ and $L 5$ and S1 levels $s^{(2,12,18)}$. In our study, which was conducted from April 2015 to April 2017, we retrospectively evaluated the patients with LDH, who underwent microsurgery. 


\section{MATERIALS AND METHODS}

A total of 282 patients with LDH, who were operated in our clinic from April 2015 to April 2017, were retrospectively analyzed. All patients were evaluated with direct lumbosacral radiographs, lumbar magnetic resonance imaging (MRI) (Figure 1), and if necessary, with lumbar computed tomography (CT). Furthermore, some patients underwent electromyography (EMG) to support the diagnosis. The patients who were previously operated were retrospectively evaluated for the parameters including the gender, age, physical examination, intervertebral disc distances, radiological findings, preoperative and postoperative findings, complications, and recurrence.

\section{RESULTS}

Maximal disc resection was performed by the microsurgical technique in all patients. Of the patients, 125 were men (44.33\%) and 157 were women (55.67\%) (Table 1). The mean age was 44 (19-80) years. The distribution of patients according to age ranges is shown in Table 2. All patients complained of low back pain and unilateral or bilateral sciatica. The patients having only low back pain were not operated. On the physical examination, the Laseque test was significant $\left(<60^{\circ}\right)$ in 273 (96.8\%) patients. Of the study patients, 65 (23.04\%) patients had motor deficits at various levels, 144 (51.06\%) patients had changes in reflexes, and 178 patients (63.1\%) had dermatomal

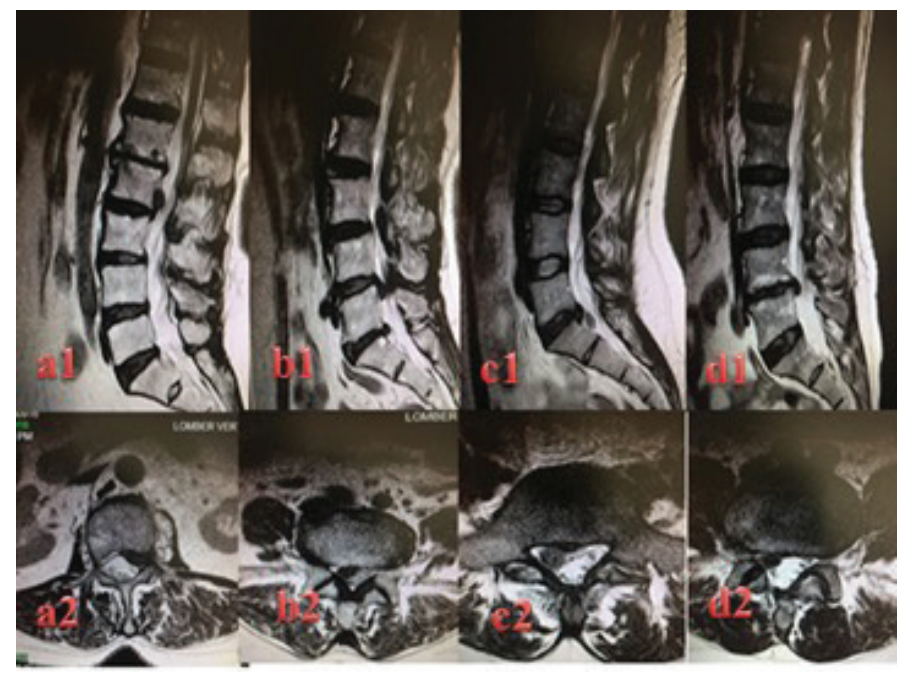

Figure 1. Magnetic resonance imaging of selected patients before the operation. a1-2: Left centrolateral disc herniation at the L2-3 level, b1-2: right centrolateral disc herniation at the L4-5 level, c1-2: right centrolateral disc herniation at the L5-S1 level, d1-2: and right centrolateral recurrent disc herniation at the L4-5 level

Table 1. Gender distribution in the study population

\begin{tabular}{lll}
\hline & Number of patients & $\%$ \\
\hline Male & 125 & 44.33 \\
\hline Female & 157 & 55.67
\end{tabular}

sensory changes (Table 3). The patient distribution according to the intervertebral disc level pathology was as follows: L1-2 level in 3 (1.06\%) patients, L2-3 level in 8 (2.84\%) patients, L3-4 level in 32 (11.35\%) patients, and L4-5 level in 103 (36.52\%) patients. There were 61 (21.63\%) patients with LDH at the L5S1 level. Also, the disc herniation was two levels in 61 patients (21.63\%), three levels in 13 patients (4.61\%) and four levels in one patient $(0.35 \%)$. All of these patients were operated. Among all patients, 8 patients $(2.84 \%)$ underwent repeat operations (Table 4). All patients received one dose of preoperative and 2 doses of postoperative prophylactic antibiotic therapy. The skin of all patients was brushed with antiseptic solutions for 5 minutes before the operation. The intervertebral distance was determined by perioperative scopy. A 2-3 cm skin incision was performed in the lumbar area on the midline (Figure 2). All of the patients were operated with the microsurgical technique with maximal disc resection (Figure 3). There was dura injury in

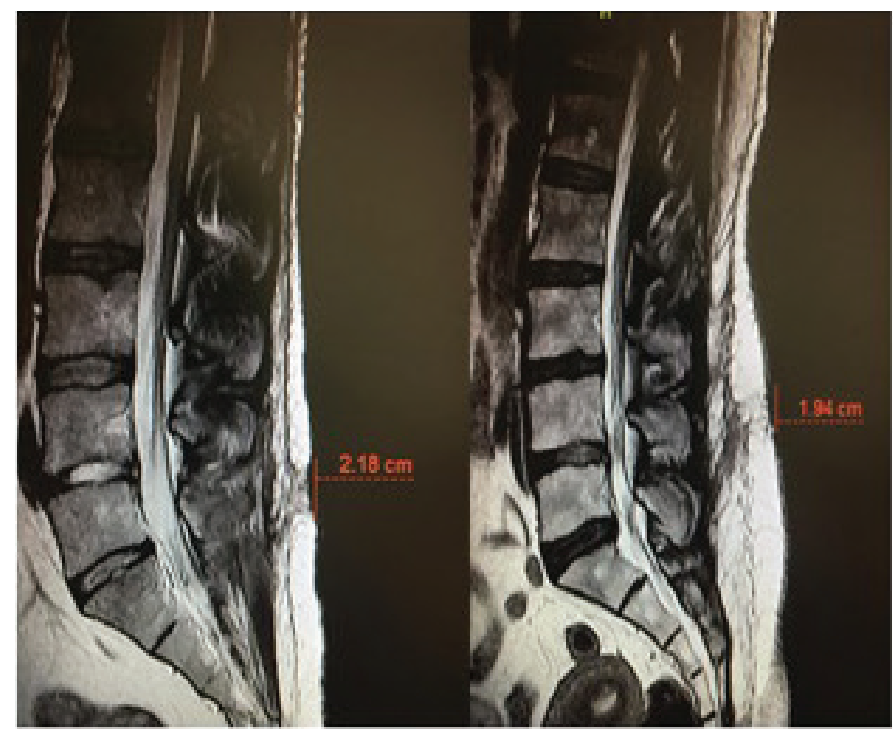

Figure 2. Postoperative magnetic resonance imaging of a skin incision

Table 2. Distribution of patients by the age groups

\begin{tabular}{|lll|}
\hline & Number of patients & $\%$ \\
\hline $10-29$ years & 23 & 8.16 \\
\hline $30-49$ years & 173 & 61.35 \\
\hline 50 years and older & 86 & 30.49 \\
\hline
\end{tabular}

Table 3. Physical examination findings of the study patients before surgery

\begin{tabular}{lll}
\hline & Number of patients & $\%$ \\
\hline Motor deficits & 65 & 23.04 \\
\hline Reflex changes & 144 & 51.06 \\
\hline Sensory changes & 178 & 63.1 \\
\hline Laseque test & 273 & 96.8 \\
\hline Femoral tensile test & 55 & 19.5
\end{tabular}


turkishspine

9 (3.19\%) patients. Two of these patients had previously been operated in external clinics. Cerebrospinal fluid (CSF) collection developed in one $(0.35 \%)$ patient and this patient was treated with ultrasound-guided needle aspiration intermittently. Accidentally, one (0.35\%) patient underwent laminotomy at an erroneous intervertebral disc level. Spondylodiscitis developed in one $(0.35 \%)$ patient but this patient recovered totally after

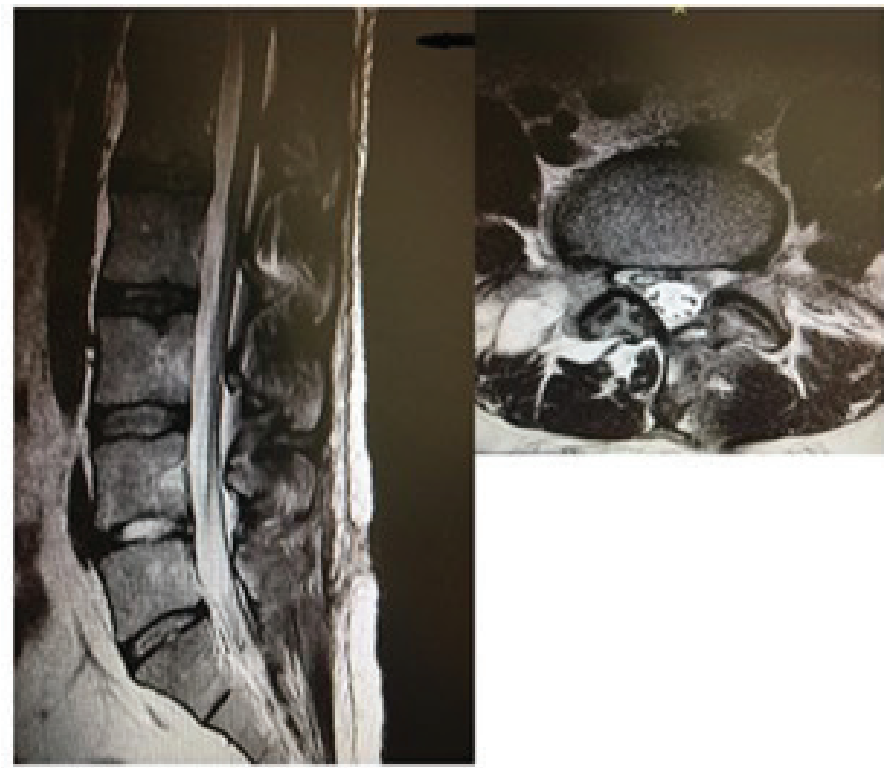

Figure 3. Postoperative magnetic resonance imaging of a left disc herniation at the L4-5 level

Table 4. Levels of discectomy

\begin{tabular}{lll|}
\hline & Number of patients & $\%$ \\
\hline L1-2 & 3 & 1.06 \\
\hline L2-3 & 8 & 2.84 \\
\hline L3-4 & 32 & 11.35 \\
\hline L4-5 & 103 & 36.52 \\
\hline L5-S1 & 61 & 21.63 \\
\hline Two levels & 61 & 21.63 \\
\hline Three levels & 13 & 4.61 \\
\hline Four levels & 1 & 0.35
\end{tabular}

Table 5. Complications

\begin{tabular}{lll}
\hline & $\begin{array}{l}\text { Number of } \\
\text { patients }\end{array}$ & $\%$ \\
\hline Dura injury & 9 & 3.19 \\
\hline BOS subcutaneous collection & 1 & 0.35 \\
\hline Incorrect distance & 1 & 0.35 \\
\hline Spondylodiscitis & 1 & 0.35 \\
\hline Superficial skin infection & 2 & 0.71 \\
\hline Recurrence & 8 & 2.84
\end{tabular}

medical treatment. In two (0.71\%) patients, superficial infections developed in the incision site. These infections recovered after medical treatment and wound debridement. Post-traumatic spondylolisthesis developed in one $(0.35 \%)$ patient in the postoperative period. Recurrences occurred in eight $(2.84 \%)$ patients (Table 5). Patients were evaluated postoperatively in the first week. The Prolo scale was administered to the patients in the third month. It was found out that our surgical results were excellent (48.58\%) in 137 patients, good (43.97\%) in 124 patients, moderate $(7.09 \%)$ in 20 patients, and poor in one $(0.35 \%)$ patient (Table 6). Excellent results indicated that the complaints of the patient were resolved completely and the patient returned to daily functioning. Good results indicated that the patient returned to work and daily activities but with mild complaints occurring at some times. Moderate results indicated that the patient was unable to perform in the previous work and the patient had to work in a less strenuous job. A comparison of the preoperative and postoperative radicular pain levels revealed a significant reduction in postoperative radicular pain $(p<0.001)$. The patients reporting that they did not benefit from the operation and that their complaints remained were considered to be in the "poor results" group. Overall, $93 \%$ of our patients reported that they benefited from the surgery.

\section{DISCUSSION}

It is established that $70-80 \%$ of people suffer from low back pain at some time in their lives ${ }^{(2,18,24,25)}$. However, only $1-2 \%$ of the patients presenting to the outpatient clinics with low back pain require surgical treatment at the end of a series of examinations and treatments. LDH usually occurs in men more frequently and this frequency varies from 65 to $80 \%(7,16,26)$. In our study, $44.33 \%$ of our patients were men. Compared to the literature, the number of female patients in our study was higher.

LDH is frequently seen in the $3^{\text {rd }}, 4^{\text {th }}$, and $5^{\text {th }}$ decades of the lifespan. As the underlying reason, it is suggested that the individuals are more active in these decades compared to the other ages in the lifespan ${ }^{(13,22,29)}$. In our patient series, LDH was most commonly observed in the age group of 30-49 years (61.35\%). Our results were in alignment with the findings reported in the literature.

The examination findings of the operated patients showed that the Laseque sign was significantly positive in 273 patients (96.8\%). In the literature, it has been reported that the Laseque

Table 6. Clinical results according to the Prolo follow-up criteria

\begin{tabular}{lll}
\hline & Number of patients & $\%$ \\
\hline Excellent & 137 & 48.58 \\
\hline Good & 124 & 43.97 \\
\hline Moderate & 20 & 7.09 \\
\hline Poor & 1 & 0.35
\end{tabular}


sign is positive in $83 \%$ of cases suffering from nerve root compression $^{(3)}$. Furthermore, our patients suffered from various levels of strength loss (23.04\%), dermatomal sensory changes (63.1\%), and reflex changes (51.06\%). It was found out that these rates were compatible with the literature ${ }^{(1,14)}$. On the same day, 11 (3.9\%) patients were treated due to advanced neurological deficits (drop foot, paraparesis or urinary-stool incontinence) under emergency conditions. In 8 (72.7\%) of these patients, complete neurological recovery occurred; however, the recovery was partial in one $(9.1 \%)$ patient and no neurological improvements were observed in two (18.2\%) patients. LDH is mostly seen at the intervertebral disc levels of L4-5 or L5-S1 due to the impact of biomechanical effects on the lumbar spinal column with a frequency of $80-90 \%$ in the literature ${ }^{(15,26)}$. This rate was found to be $84.75 \%$ in our study in line with the literature. Lumbosacral radiographs, lumbar intrathecal contrast-enhanced and non-contrast $\mathrm{CT}$ images, myelography and EMG findings, and MRI can be used in making the diagnosis of $\operatorname{LDH}^{(11,15)}$. Besides showing the herniated lumbar disc pressing on the nerve root or dural sac outside the disc distance, MRI also reveals signal changes within the suspected disc degeneration distance ${ }^{(4)}$. In our series, direct lumbosacral radiographs and lumbar MRI were used in making the diagnosis in all patients. The diagnoses were supported by EMG and CT findings in some patients.

Perioperative and early postoperative complications may be encountered in LDH operations. These complications include superficial or deep infections of the wound site, infection in the intervertebral distance, dural tears and neural tissue injuries, major vascular injury, and ureter damage ${ }^{(5,6,8,23,26-28,30)}$. In our series, 9 (3.19\%) patients had dural injury. Two of these patients had been operated previously. CSF collection developed in one $(0.35 \%)$ patient, who was treated with ultrasound-guided needle aspiration intermittently. It was found out that one $(0.35 \%)$ patient underwent laminotomy accidentally at an incorrect intervertebral disc distance. Spondylodiscitis developed in one $(0.35 \%)$ patient and improved after medical treatment. In two $(0.71 \%)$ patients, a superficial infection developed in the skin incision and improved after medical treatment combined with wound debridement. Spondylolisthesis was observed in one $(0.35 \%)$ patient in the postoperative $8^{\text {th }}$ month. The patient had a history of trauma in the postoperative period. Spondylolisthesis was thought to be secondary to trauma. We considered that compliance with microsurgical principles and maximum disc resection enabled to achieve the low rates of complications and recurrent disc herniation.

Williams argued that removing only free disc fragments was sufficient to avoid creating injury in the healthy disc, reporting a recurrence rate of $9 \%{ }^{(27)}$. Similarly, Rogers ${ }^{(23)}$ reported a recurrence rate of $11 \%$ in cases, where only the disc fragment was removed. Yaşargil(28) and Caspar et al. ${ }^{(6)}$ reported a recurrence rate of $4 \%$ in the patients undergoing maximum resection $^{(8)}$. In our series, maximum resection was performed and $8(2.84 \%)$ patients had a recurrence during the followup period. This rate corresponds to the series that advocate maximum resection. When we compared the symptoms of the patients before and after the surgery, we observed a statistically significant reduction in the symptoms compared to the preoperative values $(p<0.001)$. The Prolo scale is widely used in evaluating postoperative improvement in patients ${ }^{(10,21)}$. Various patient series in the literature report that the achieved results are "good" with rates from 74 to $93 \%\left({ }^{(10)}\right.$.

\section{CONCLUSION}

In our series, excellent results were obtained in 137 patients $(48.58 \%)$ and good results were obtained in 43 patients (43.97\%) as determined in the postoperative follow-up visits (Table 6). Our results were considered to be in alignment with the literature. In this study, 282 patients with LDH underwent surgical treatment with microsurgical technique and maximum resection principle. The outcomes of surgery were evaluated in the patients. Our study results were in line with the results reported in the literature. Our results showed that in selected cases requiring surgery, the microsurgical technique with maximum disc resection was an effective and reliable method for the surgical treatment of LDH.

\section{Ethics}

Ethics Committee Approval: All procedures performed in this study were conducted in compliance with the ethical standards of the institutional ethics committee of Medipol University and with the 1964 Helsinki Declaration and its later amendments or comparable ethical standards. Retrospective study.

Informed Consent: Informed consent was obtained from all individual participants included in the study.

Peer-review: Internally peer-reviewed.

\section{Authorship Contributions}

Surgical and Medical Practices: G.B., Concept: G.B., M.H.A., M.G., Design: G.B., Data Collection or Processing: G.B., M.H.A.,Analysis or Interpretation: M.H.A., M.G., Literature Search: M.G., Writing: M.H.A., M.G.

Conflict of Interest: No conflict of interest was declared by the authors.

Financial Disclosure: The authors declared that this study received no financial support.

\section{REFERENCES}

1. Akdemir H, Paşaoğlu A, Selçuklu A, Kurtsoy A, Işman L. Lumbar disk hernilerinde reoperasyon. Erciyes Tıp Dergisi 1990;12:370-6.

2. Alptekin H K, Dıraçoğlu D, Karan A. 13 Yaşında Lumbar Disk Olgusu. Ist Tip Fak Derg 2010:73-4.

3. Blaauw G, Braakman R, Gelpke G), Singh R. Changes in radicular function following Low-Back Surgery. J Neurosurg 1988;69:649-52.

4. Boden SD, Davis DO, Dina TS, Patronas NJ, Wiesel SW. Abnormal magnetic-resonance scans of the lumbar spine in asymptomatic patients. J Bone Joint Surg 1990;72:403-8.

5. Buharalı Z, Karadayı A, Cordan T, Avman N. Disk hernilerinin cerrahi tedavisi. Cerrahi olarak tedavi edilen 295 vakanın değerlendirilmesi. Ankara Üniv Tıp Fakültesi Mecmuası 1971;5:910-9. 
turkishspine

6. Caspar W, Campbell B, Barbier DD, Kretschmmer R, Gotfried Y. The Caspar microsurgical discectomy and comparison with a conventional standart lumbar disc prosedure. Neurosurgery 1991;28:78-86.

7. Çelik RB. Lumbar Herni Diskal. Aktüel Tıp Dergisi 1997;1:674-8.

8. Conrad T, Pappas E, Harrington T, Sonntag H. Outcome analysis in 654 surgically treated lumbar disc herniations. Neurosurgery 1992; 30:862-6.

9. Davis JR. CH: Extradural spinal cord and nerve root compression from benign lesions of the lumbar area. Youmans JR (ed) W.B.Sounders company 1973,63 pp.1165-85.

10. Demirbaş MA. Üst seviye lumbar disk hernilerinde insidans, klinik özellikler, tanı ve tedavi yöntemlerinin değerlendirilmesi. 2000; Uzmanlık tezi: Haydarpaşa Numune Eğitim ve Araştırma Hastanesi.

11. Deyo RA, Bigos SJ, Moravilla KR. Diagnostic imaging procedures for the lumbar spine. Ann Intern Med 1989;111:865-7.

12. Epstein SS. The spine. A radiological text and atlas. 4.th edition Leo Febigor, Philadelphia. ch31,pp 617-62; ch 33, pp 632-658, 1976.

13. Eugene J, Kim DH. A prospective analysis of magnetic rezonance imaging findings in patients with sciatica and LDH. Spine 1997;22:1650-60.

14. Fager CA. Ruptured median and paramedian lumbar disc: A review of 243 cases. Surg Neurol 1985;23:309-23.

15. Herthoff KD, Burton CV. CT evaluation of the failed back surgery syndrome. Orthop Clin North Am 1985;16:417-4.

16. Kuday C. Bel ağrıları tanı ve tedavisi: Logo Yayıncılık A.Ş. İstanbul 1993;1-28.

17. Lee JY, Ernestus RI, Schroder R, Klug N. Histological study of lumbar intervertebral disc herniation in adolescents. Acta Neurochir (Wien) 200;142:1107-10.

18. Pappas CTE, Harrington T, Sonntag VKH. Outcome analysis in 654 surgically treated lumbar disc herniations. Neurosurgery 1992;30:862-6.
19. Parisini P, Di Silvestre M, Greggi T, Miglietta A, Paderni S. Lumbar disc excision in children and adolescents. Spine 2001;26:1997-2000.

20. Paşaoğlu A, Selçuklu A. Lumbal disk hernilerinin klinik analizi ve cerrahi tedavi sonuçları. Erciyes Üniversitesi Tıp Fakültesi Dergisi 1983;5:217-24.

21. Prolo DJ, Oklund SA, Butcher M. Toward uniformity in evaluating results of lumbar spine operations. Spine 1986;11:601-6.

22. Rastecchini F. Results of surgery compared with conservative management for lumbar disc herniations. Spine 1991;21:1383-7.

23. Rogers LA. Experience with limited versus extensive disc removal in patients undergoing microsurgical operations for ruptured lumbar disc. Neurosurgery 1988;22:82-5.

24. Tekeoğlu I, Göksoy T, Gürbüzoğlu N. Bel ağrılı 100 olgunun klinik ve radyolojik yönden değerlendirilmesi. Van Tıp Dergisi 19985:72-5.

25. Virta L, Ronnemsa T, Osterman K, Alto T, Laakso M. Prevelance of isthmic lumbar spondylolisthesis in middle aged subjects from easthern and Western Finland. J Clin Epidemiol 1992;45:917-22.

26. Weir BKA. Prospective study of 100 lumbosacral discectomies. J Neurosurgery 1979;50:287-9.

27. Williams RW. Microdiscectomy-myth, mania or mile stone? An 18 years surgical adventure. Adv Neurosurgery 1977;4:81-7.

28. Yaşargil MG. Microsurgical operation of the herniated lumbar disc. Adv Neurosurgery 1977;4:81-7.

29. Yasuma T, Arai K, Yamauchi Y. The histology of lumbar intervertebral disc herniations. Spine 1993;18:1761-5.

30. Yıldızhan A, Aral Ö, Uluer Ş, Arslan C, Ergün J, Kafalı N, et al. Lumbar disk hernileri: Opere edilen 327 vakanın klinik analizi. Bezm-i Alem Valide Sultan Vakıf Gureba Hastanesi Dergisi 1990;17:41-4. 